\title{
Plasma Levels of Glial Cell Marker S100B in Children With Autism
}

\author{
A. TOMOVA ${ }^{1}$, P. KEMÉNYOVÁ ${ }^{1}$, D. FILČÍKOVÁ ${ }^{1}$, Ž. SZAPUOVÁ ${ }^{1}$, A. KOVÁČ ${ }^{2}$, \\ K. BABINSKÁ ${ }^{1}$, D. OSTATNÍKOVÁ ${ }^{1}$
}

${ }^{1}$ Institute of Physiology, Faculty of Medicine, Comenius University in Bratislava, Bratislava, Slovak Republic, ${ }^{2}$ Slovak Academy of Sciences, Institute of Neuroimmunology, Bratislava, Slovak Republic

Received March 21, 2019

Accepted September 26, 2019

\begin{abstract}
Summary
Autism spectrum disorder (ASD) is a neurodevelopmental condition with increasing incidence. Recent evidences suggest glial cells involvement in autism pathophysiology. S100B is a calcium binding protein, mainly found in astrocytes and therefore used as a marker of their activity. In our study, children with autism had higher plasma concentrations of $\mathrm{S} 100 \mathrm{~B}$ compared to non-autistic controls. No association of S100B plasma levels with behavioral symptoms (ADI-R and ADOS-2 scales) was found. Plasma S100B concentration significantly correlated with urine serotonin, suggesting their interconnection. Correlation of plasma S100B levels with stool calprotectin concentrations was found, suggesting not only brain astrocytes, but also enteric glial cells may take part in autism pathogenesis. Based on our findings, S100B seems to have a potential to be used as a biomarker of human neurodevelopmental disorders, but more investigations are needed to clarify its exact role in pathomechanism of autism.
\end{abstract}

\section{Key words}

S100B • Autism • Serotonin

\section{Corresponding author}

A. Tomova, Institute of Physiology, Faculty of Medicine, Comenius University in Bratislava, Bratislava, Slovakia, Sasinkova 2, 81372 Bratislava, Slovak Republic. E-mail: aleksandra.tomova@fmed.uniba.sk

\section{Introduction}

ASD (Autism spectrum disorder) is brain-based neurodevelopmental condition characterized by impairments in social communication and social interaction in the presence of restricted, repetitive behaviors or interests. ASD is of expanding worldwide medical and social concern because of its increasing incidence (Onaolapo and Onaolapo 2017, Baio et al. 2018). Despite recent scientific interest, etiology and pathogenesis of ASD remain unclear what obstructs the prevention, diagnostics and treatment of people with these disorders. According to current hypotheses, etiology of ASD involves multiple mechanisms, including genetic predisposition and environmental factors. Their combination may lead to alterations in epigenetic gene regulation, with consequences including impairments in neuron-glia interactions (Zeidan-Chulia et al. 2014). Mounting evidence suggests the role of neuroglial cells in autism, as well as in other neurological, neurodevelopmental and psychiatric disorders. Neuroglia described in 1858 by Virchow is represented by macroglia and microglia. The role of microglia is characterized in several reviews (Koyama and Ikegaya 2015, Tay et al. 2017, Anderson and Vetter 2019). Astrocytes, representatives of macroglia, are involved in neurogenesis, development and maintenance of homeostasis in the brain, neurotransmitter signaling, neuronal activity and mitochondrial functions in neural cells (Zeidan-Chulia et al. 2014). Since ASD is characterized by deviations in brain development, neurogenesis, synaptopathy and neuroinflammation (Gilbert and Man 2017), investigation of astrocytes and their products seems to be a reasonable and promising objective within surveys aimed at elucidating the autism pathogenesis.

$\mathrm{S} 100 \mathrm{~B}$ is one of markers of astrocyte activation. It is a $\mathrm{Ca}^{2+}$ (calcium)-binding protein, concentrated 
mainly in intracellular compartment and found extracellularly when actively released or in case of the leakage from damaged cells. The intracellular role of S100B includes participation in cell proliferation, differentiation, transcription, survival, enzyme activities. Its extracellular role is exerted mostly through receptors for advanced glycation end-products (RAGE) and triggering intracellular signaling cascade, that leads to processes such as neuroinflammation and neurodegeneration (for review see Sorci et al. 2013, Michetti et al. 2019). Interestingly, through this activation S100B has been shown to regulate microglia activation and migration, as well as to eventually cause neuronal death (Bianchi et al. 2011).

Since S100B is released from damaged astrocytes, its increased extracellular concentration might be used as a biomarker of acute brain injury, neural distress, and, possibly, neurodegenerative disorders.

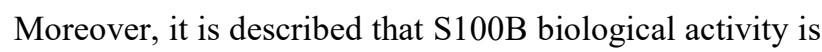
associated with its concentration (Michetti et al. 2019). However, for interpretation of $\mathrm{S} 100 \mathrm{~B}$ role in pathophysiology it is important to remember, that in neural cultures it demonstrated neurotrophic effects at nanomolar levels, while apoptotic effects at micromolar levels (Sorci et al. 2013, Michetti et al. 2019). For example, in nanomolar concentrations S100B has been shown to exert neurotrophic and neuroprotective effects on serotonergic neurons (Eriksen and Druse 2001). For last decades, $\mathrm{S} 100 \mathrm{~B}$ has been shown to be a reliable biomarker of neural injury (Astrand and Unden 2019, Michetti et al. 2019). It is actively investigated as a possible biomarker in such disorders as Alzheimer's disease, Parkinson's disease, Schizophrenia, or mood disorders (for review see Michetti et al. (2019)) and others. However, if is it possible to use it as a marker in patients with neurodevelopmental disorders, including autism, remains unclear. The main goal of our study was to investigate the plasma concentrations of $\mathrm{Ca}^{2+}$ binding protein $\mathrm{S} 100 \mathrm{~B}$, as a biomarker of the status of astrocytes in central nervous system and glial cells in enteric nervous system in children with and without autism, and its possible correlation with their behavior.

Additionally, in attempt to elucidate the mechanism of autism, in a randomly selected fraction of children with autism $(n=30)$ urine was analyzed for serotonin levels. Serotonin (5-hydroxytryptamin, 5-HT) is a neurotransmitter, well known for its pleiotropic effects, including role in the central nervous system and behavior (Frazer and Hensler 1999, Mohammad-Zadeh et al. 2008). This molecule is also actively investigated in connection to ASD. Evidence suggests that increased or decreased serotonin level plays a critical role in neurodevelopment (Garbarino et al. 2019). The involvement of serotonin in ASD pathomechanisms is widely supported by findings that behavioral symptoms of autism, including deficits in social behavior (Kiser et al. 2012) and restrictive repetitive behaviors (Hollander et al. 2005), are modulated by 5-HT signaling. Some studies showed increased blood levels of serotonin in children with autism (Abdulamir et al. 2018), but other studies reported this might be a result of high level of hyperserotonemia not in all, but in approx. $25 \%$ of people with ASD (Gabriele et al. 2014, Marler et al. 2016). At the same time, serotonin is a neurotransmitter that is produced in large quantities in the gastrointestinal tract (Jameson and Hsiao 2018). We choose to study serotonin levels in urine not only because it is a noninvasive procedure, but 5-HT levels in plasma and urine are shown to correlate (Audhya et al. 2012). There is even a study, reporting that hyperserotonemia increases 5-HT level in urine in individuals autism (Mulder et al. 2010).

In the presented study, we investigated serotonin levels in connection to $\mathrm{S} 100 \mathrm{~B}$, since according to scientific evidence their actions seem to be interconnected. Most of serotonin effects are mediated through the release of S100B (Shapiro et al. 2010).

The level of S100B in the periphery comprises its release from glial cells in the brain and in the intestinal tract. Enteric glial cells (EGCs) are responding to gut inflammation (Langness et al. 2017), which can be approximated by measuring fecal calprotectin levels. Calprotectin is routinely used as a validated non-invasive marker of intestinal inflammation (Alibrahim et al. 2015). In inflammatory bowel disease it is used to evaluate the severity of disease and the response to treatment (Erbayrak et al. 2009, Alibrahim et al. 2015). It can be used also as a marker of gastrointestinal status in children with autism (Babinska et al. 2017).

\section{Methods}

\section{Subjects}

The study included 93 children diagnosed with autism and 35 non-autistic children. The age of children with autism was $6.22 \pm 0.30$ years (mean \pm SEM), ranging from 2 to 16 years, and matching control group of children aged $6.99 \pm 0.59$ years (mean \pm SEM), ranging 
from 2 to 12 years. All children were boys. Children were recruited from the Academic Research Center for Autism (ARCA), based at the Institute of Physiology, Faculty of Medicine Comenius University in Bratislava. The diagnosis of ASD was performed meeting criteria for DSM-V (The Diagnostic and Statistical Manual of Mental Disorders, Fifth Edition), using Autism Diagnostic Observation Schedule - second edition (ADOS-2) (Lord et al. 2012), and the Autism Diagnostic Interview-Revised (ADI-R) (Lord et al. 1994). ADOS-2 was evaluated in domains of social affect (SA), and restricted and repetitive behavior (RRB) scores, and total raw score. ADI-R was evaluated in areas of qualitative abnormalities in reciprocal social interaction (A) and communication (B), as well as in restricted, repetitive and stereotyped patterns (C) of behavior. All subject involved in the study met criteria for ASD on both ASD diagnostic tools.

Exclusion criteria included genetic disorders, speech disorders and medication use. Children's parents signed the written consent to participate in this project. The protocol was approved by the Ethics Committee of the University Hospital and Comenius University Faculty of Medicine in Bratislava, Slovakia. The study conformed to the code of ethics stated in the Declaration of Helsinki of the World Medical Association.

\section{Laboratory methods}

Blood samples with EDTA were centrifuged $3000 \mathrm{rpm}$ for $10 \mathrm{~min}$ and aliquoted to store frozen at $-80^{\circ} \mathrm{C}$ until analysis was performed. Plasma S100B level was detected using ELISA method with sensitivity of $15.6 \mathrm{pg} / \mathrm{ml}$ and detection range from $15.6 \mathrm{pg} / \mathrm{ml}$ to $1000 \mathrm{pg} / \mathrm{ml}$ according to manufacturer's instructions (LifeSpan BioSciences, Inc., USA). The absorbance was measured spectrophotometrically at $450 \mathrm{~nm}$ wavelength (Epoch, Biotek).

Stool specimens were collected by parents, kept at $4{ }^{\circ} \mathrm{C}$ and delivered to our laboratory within $12 \mathrm{~h}$, where aliquots of $200 \mathrm{mg}$ of each specimen were frozen at $-80{ }^{\circ} \mathrm{C}$ until analysis. Calprotectin extraction was performed with Calpro EasyExtract (Calprolab, Lysaker, Norway). Its determination in 1:50 diluted extracts was performed using CALPROLAB ${ }^{\mathrm{TM}}$ Calprotectin ELISA (ALP) (Calprolab, Lysaker, Norway) according to the instructions provided by the manufacturer.

In 30 randomly chosen children from the individuals with autism urine was analyzed. Urine samples were collected by parents and delivered to the laboratory within $3 \mathrm{~h}$, where frozen at $-20^{\circ} \mathrm{C}$ until analysis. Serotonin levels were measured by UHPLC/MS/MS method using the AbsoluteIDQ ${ }^{\circledR}$ p180 kit (Biocrates Life Sciences AG, Innsbruck, Austria), UPLC-Xevo TQS. Sample preparation and measurements were carried out according to the manufacturer's protocol and have been described in detail elsewhere (WangSattler et al. 2008). Serotonin concentrations were normalized to creatinine levels as earlier described (Tang et al. 2015).

\section{Data analysis}

Data were analyzed using $t$-test to evaluate the differences between groups. Data are presented as means \pm SEM. For data correlation Pearson correlation coefficients were used. $\mathrm{p}<0.05$ were considered significant. For all statistical analyses, Software GraphPad Prism 5 and Microsoft Excel 2016 were used.

\section{Results}

In this study, children with autism had significantly higher plasma levels of S100B compared to non-autistic children (Fig. 1), $\mathrm{p}=0.028$. S100B concentrations were $33.04 \pm 3.35 \mathrm{pg} / \mathrm{ml}, \mathrm{N}=89$ in the study group vs. $23.26 \pm 2.86 \mathrm{pg} / \mathrm{ml}, \mathrm{N}=34$ in the control group, 4 and 1 outliers from the groups correspondingly were excluded. This supported the hypothesized theory of S100B involvement in the ASD pathogenesis. We did not observe correlation with any of the behavioral markers represented by three subscales of ADI-R, two subscales ADOS-2 or with its total raw score. Plasma S100B concentration was not age related.

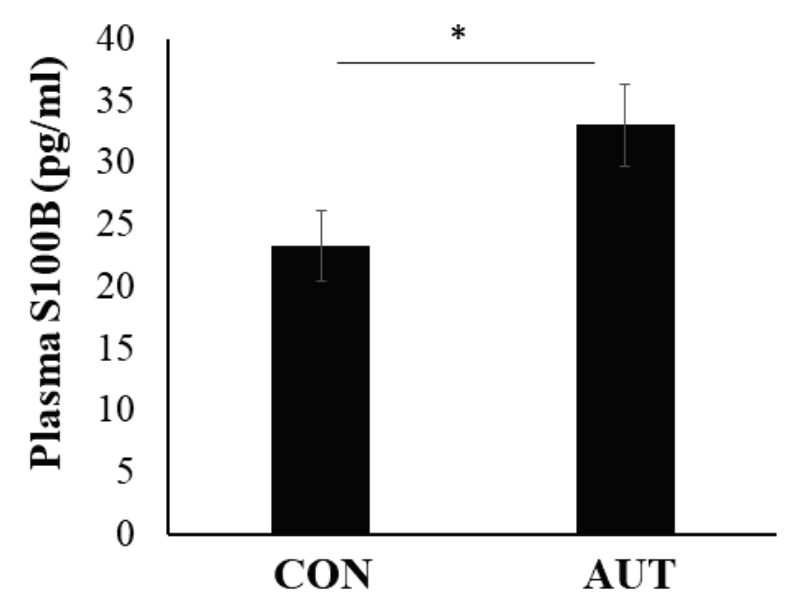

Fig. 1. Plasma levels of $S 100 B(\mathrm{pg} / \mathrm{ml})$ in children with autism (AUT) and in non-autistic controls (CON), ${ }^{*} p<0.05$ 


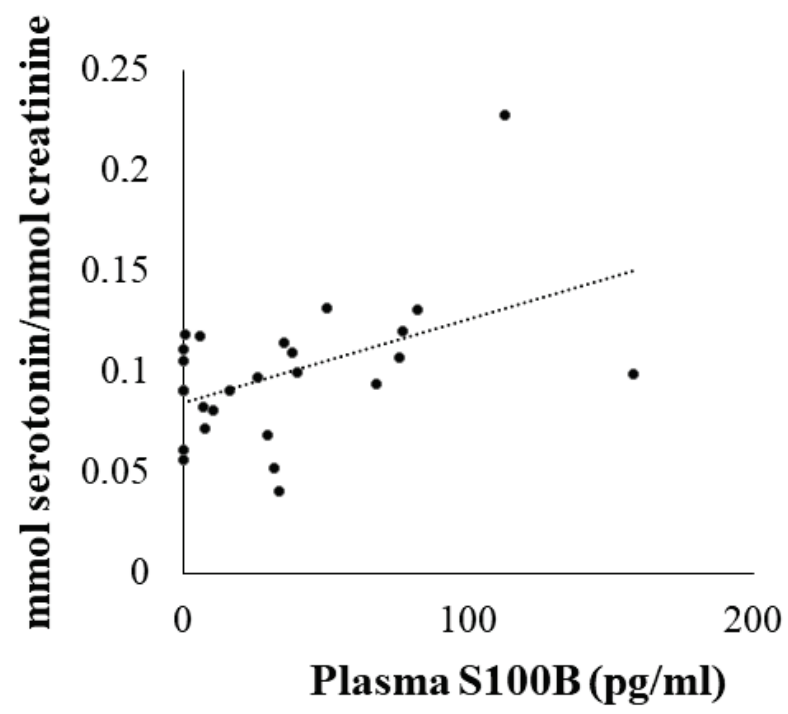

Fig. 2. Correlation between plasma levels of $\mathrm{S} 100 \mathrm{~B}(\mathrm{pg} / \mathrm{ml})$ and urine levels of serotonin, normalized to creatinine level, in children with autism, Pearson coefficient $0.47,{ }^{* *} p<0.01$.

We found a significant positive correlation between plasma levels of S100B and urine levels of serotonin (Pearson correlation coefficient 0.47, $\mathrm{p}=0.007$ ) (Fig. 2).

Evaluated calprotectin from stool samples of children with autism showed a weak, but significant positive correlation with S100B, Pearson coefficient 0.21, $\mathrm{p}=0.037$ (Fig. 3).

\section{Discussion}

ASD is a group of neurodevelopmental disorders, not only etiology of which remains uncertain, but its pathogenesis is also only partially understood. Past decade of investigations brought a growing comprehension of a possible involvement of neuroglia in ASD pathogenesis.

$\mathrm{S} 100 \mathrm{~B}, \mathrm{Ca}^{2+}$-binding protein, is mainly concentrated in astrocytes and passively released from them in brain injury, increasing its CSF (cerebrospinal fluid) and blood levels. It is already generally accepted that S100B is a reliable biomarker of acute neural distress, bloodbrain barrier integrity and as a control of the effectiveness of its treatment (Astrand and Unden 2019, Michetti et al. 2019). It has been shown that CSF S100B levels are highly correlated with plasma S100B levels (Huang et al. 2010). S100B plasma concentration reflects blood-brain barrier permeability (Marchi et al. 2003) even in absence of acute brain injury (such as stress, neurodegenerative disorders) (Michetti et al. 2019, Xu et al. 2019).

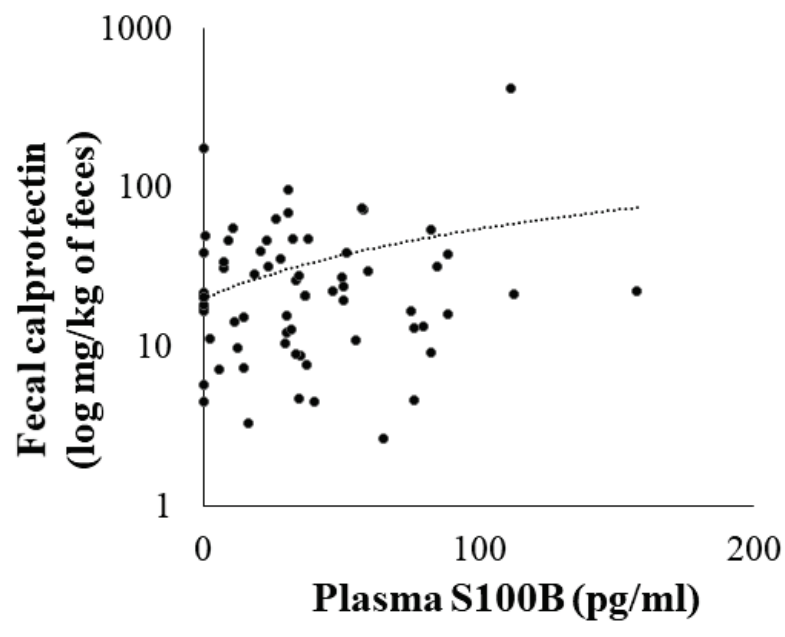

Fig. 3. Correlation between plasma levels of $\mathrm{S} 100 \mathrm{~B}(\mathrm{pg} / \mathrm{ml})$ and fecal calprotectin levels (log $\mathrm{mg} / \mathrm{kg}$ of feces), in children with autism, Pearson coefficient $0.21,{ }^{*} \mathrm{p}<0.05$.

Our study revealed augmented levels of S100B in plasma of children with autism, compared to control children, what is in concordance with earlier described hypothesis of increased S100B in ASD. There is indication that this may be a consequence of dysregulation of neuron-glia interactions, resulting from altered epigenetic gene regulation and oxidative stress (Zeidan-Chulia et al. 2014). Although elevated concentration of $\mathrm{S} 100 \mathrm{~B}$ has a pro-inflammatory function with the main goal to activate macrophages and trigger the process of repair and regeneration in case of damage (Sorci et al. 2013), it also increases free radical production, facilitating death of neurons and glia (Bianchi et al. 2011, Michetti et al. 2019). The main pathway of extracellular S100B is RAGE (Receptor for Advanced Glycation End-products) dependent, activating different cell types, mediating a series of pathological conditions, including neuroinflammation. Remarkably, extracellular elevated S100B activates a RAGE-dependent autocrine loop in astrocytes, turning them into a pro-inflammatory/neurodegenerative phenotype what facilitates neuronal death (Villarreal et al. 2014). This might be associated with the recent finding of lower number of neurons in the amygdala of people with ASD (Avino et al. 2018), especially in context of social deficits in people with autism. Thus, our findings are in agreement with the theory of "autism as a glial pathology" (ZeidanChulia et al. 2014).

Although our investigation found a significant increase of plasma S100B in children with autism compared to controls, it did not reveal any significant correlation with behavioral patterns. Similar results were 
obtained by another research group (Shaker et al. 2016), investigating 30 children with autism and 22 control children. These observations are not consistent in the literature, though. A study, including 40 children with autism reported not only their increased S100B concentrations, but its association with autism severity (Guloksuz et al. 2017). Contrary, one study with 35 children with ASD found no difference in serum S100B with controls (Esnafoglu et al. 2017). This discordance in results could be based on small groups of included children, amongst which our study was the largest. The reason could be in different permeability of blood-brain barrier (BBB) for S100B.

Another possible explanation lies in the source of S100B. As mentioned before, S100B has been shown to be found mostly in brain astrocytes, but also in other glial cells, such as oligodendrocytes, Schwann cells, and enteric glial cells (EGCs). The changed microbiota in children with autism (Tomova et al. 2015) might be a reason to induce intestinal inflammation, converting EGCs to "reactive EGCs", causing alteration of S100B expression. Thus, the expression of the glial S100B protein is increased in inflammatory processes in response to the disruption of the intestinal barrier (OchoaCortes et al. 2016), that has been reported in ASD. Even pathogenic bacteria themselves and their products induce S100B release by EGCs (Ochoa-Cortes et al. 2016), suggesting this process takes place in dysbiosis, present in ASD. Maybe a comparison of GI (gastrointestinal) status in the above-mentioned studies would clarify this hypothesis. In this research, we used an objective marker of GI inflammation status - fecal calprotectin. In our previous study, we have demonstrated higher fecal calprotectin levels indicating the low-grade inflammation in guts of children with autism (Babinska et al. 2017). Our present results show low, but significant correlation of stool calprotectin levels with plasma S100B concentrations, suggesting the involvement of EGCs in S100B increased release in ASD individuals. Besides, it is known, that EGC similarly to brain glial cells participate in synaptic signaling and they may regulate synaptic plasticity and network excitability, and inflammation (Ochoa-Cortes et al. 2016). However, we should keep in mind that, on the other side, changed S100B alters enteric glial differentiation (Hao et al. 2017). Thus, S100B released from glial cells in the brain or in the gastrointestinal tract participate in gut-brain interconnection, but unfortunately, peripheral concentration of S100B does not define its source.
In case of use of S100B as a maker, it has advantages, that it can be detected in different biological fluids, as CSF, blood, saliva, urine, importantly for patients since it can be determined based on noninvasive interventions (Gazzolo et al. 2019). The challenge of use of $\mathrm{S} 100 \mathrm{~B}$ is its concentration dependence on the age (Portela et al. 2002), and therefore importance of its comparison to corresponding reference values (Bouvier et al. 2011), is crucial for early diagnosis of ASD, what improves the outcomes of interventions (Landa 2018).

Interesting finding of our study is moderate significant positive correlation between plasma levels of S100B and urine levels of serotonin. Their interconnection has been shown before: serotonin increases the release of S100B (Haring et al. 1993), S100B increase decreases serotonin (Liu et al. 2011) in the brain and S100B promotes development of serotonin terminals (Schulte et al. 2014). It is believed that serotonin effects are mediated through S100B (for review see (Shapiro et al. 2010). On the other hand, in astrocytes S100B interacts with serotonin receptor 5-HT7 affecting behavior, as shown in mice (Stroth and Svenningsson 2015).

Thus, their interaction is known, but to our best knowledge, this study is the first to reveal the correlation of their concentrations in different biological liquids: $\mathrm{S} 100 \mathrm{~B}$ in plasma and serotonin in urine.

Serotonin participation in autism pathogenesis is suggested, firstly, because augmented blood levels of serotonin have been observed in children with autism, at least in a subgroup of them (25\%) (Marler et al. 2016). Secondly, dysregulation of serotonin (increase or decrease) causes behavioral changes, characteristic for autism spectrum disorder (Garbarino et al. 2019). Since serotonin has pleiotropic effects, it is hard to specify its role in ASD (for review see (Muller et al. 2016, Garbarino et al. 2019).

However, not only behavioral, but also gastrointestinal symptoms frequently accompanying autism, are found to be associated with blood serotonin concentrations in people with ASD (Marler et al. 2016). Not to underestimate serotonin role in ASD, we have to mention, that central effects of 5-HT in people are more difficult to investigate, than peripheral ones, especially if serotonin itself cannot pass the BBB (Gostner et al. 2019). All above mentioned suggest the role of serotonin, released in brain, as well as synthesized and stored in the gastrointestinal tract in ASD manifestations.

The role of both studied substances, S100B and 
serotonin, is well recognized in CNS, but their significant amount is released in the periphery also. S100B as well as serotonin seems to be involved in pathogenesis of ASD clinical representation through the bidirectional gut-brain axis. Although there is some evidence about the role of serotonin in the gut-brain axis (Israelyan and Margolis 2018), additional studies are needed to characterize the role of S100B.

\section{Limitations}

Our study reveals increased levels of plasma S100B in children with autism compared to control children in a larger group, than previously described. Even though, it is not vast enough to generalize results to the all ASD population. To our knowledge, this study firstly demonstrated the correlation of S100B and serotonin in different biological fluids (blood plasma and urine respectively). The low-grade correlation of intestinal inflammatory marker calprotectin with plasma S100B suggests the investigation of children with autism from more aspects for better interpretation of the source of S100B and its specific role in autism development.

In conclusion, plasma $\mathrm{S} 100 \mathrm{~B}$, the glial cells activity marker, was significantly elevated in our sample of 2-16 year old children with autism compared to the controls. Our results indicate its possible combined release from glial cells of central and peripheral nervous system. The S100B level in plasma correlated with serotonin levels in urine. These findings suggest S100B seems to have a potential to be used as a biomarkers of ASD, possibly in combination with other markers or in a subgroup of children with autism with some homogenic manifestations. Future work should address the molecular mechanisms and specify the role of S100B in autism pathogenesis.

\section{Conflict of Interest}

There is no conflict of interest.

\section{Acknowledgements}

Supported by grants VEGA 1/0286/18, APVV 15-0045, APVV 15-0085.

\section{References}

ABDULAMIR HA, ABDUL-RASHEED OF, ABDULGHANI EA: Serotonin and serotonin transporter levels in autistic children. Saudi Med J 39: 487-494, 2018.

ALIBRAHIM B, ALJASSER MI, SALH B: Fecal calprotectin use in inflammatory bowel disease and beyond: A minireview. Can J Gastroenterol Hepatol 29: 157-163, 2015.

ANDERSON SR, VETTER ML: Developmental roles of microglia: A window into mechanisms of disease. Dev Dyn 248: $98-117,2019$.

ASTRAND R, UNDEN J: Clinical use of the calcium-binding S100B protein, a biomarker for head injury. Methods Mol Biol 1929: 679-690, 2019.

AUDHYA T, ADAMS JB, JOHANSEN L: Correlation of serotonin levels in CSF, platelets, plasma, and urine. Biochim Biophys Acta 1820: 1496-1501, 2012.

AVINO TA, BARGER N, VARGAS MV, CARLSON EL, AMARAL DG, BAUMAN MD, SCHUMANN CM: Neuron numbers increase in the human amygdala from birth to adulthood, but not in autism. Proc Natl Acad Sci US A 115: 3710-3715, 2018.

BABINSKA K, TOMOVA A, CELUSAKOVA H, BABKOVA J, REPISKA G, KUBRANSKA A, FILCIKOVA D, SIKLENKOVA L, OSTATNIKOVA D: Fecal calprotectin levels correlate with main domains of the autism diagnostic interview-revised (ADI-R) in a sample of individuals with autism spectrum disorders from Slovakia. Physiol Res 66 (Suppl 4): S517-S522, 2017.

BAIO J, WIGGINS L, CHRISTENSEN DL, MAENNER MJ, DANIELS J, WARREN Z, KURZIUS-SPENCER M, ZAHORODNY W, ROBINSON ROSENBERG C, WHITE T, DURKIN MS, IMM P, NIKOLAOU L, YEARGIN-ALLSOPP M, LEE LC, HARRINGTON R, LOPEZ M, FITZGERALD RT, HEWITT A, PETTYGROVE S, CONSTANTINO JN, VEHORN A, SHENOUDA J, HALL-LANDE J, VAN NAARDEN BRAUN K, DOWLING NF: Prevalence of Autism Spectrum Disorder Among Children Aged 8 Years Autism and Developmental Disabilities Monitoring Network, 11 Sites, United States, 2014. MMWR Surveill Summ 67: 1-23, 2018. 
BIANCHI R, KASTRISIANAKI E, GIAMBANCO I, DONATO R: S100B protein stimulates microglia migration via RAGE-dependent up-regulation of chemokine expression and release. J Biol Chem 286: 7214-7226, 2011.

BOUVIER D, CASTELLANI C, FOURNIER M, DAUPHIN JB, UGHETTO S, BRETON M, LABBÉ A, WEINBERG AM, SAPIN V: Reference ranges for serum S100B protein during the first three years of life. Clin Biochem 44: 927-929, 2011

ERBAYRAK M, TURKAY C, ERASLAN E, CETINKAYA H, KASAPOGLU B, BEKTAS M: The role of fecal calprotectin in investigating inflammatory bowel diseases. Clinics (Sao Paulo) 64: 421-425, 2009.

ERIKSEN JL, DRUSE MJ: Astrocyte-mediated trophic support of developing serotonin neurons: effects of ethanol, buspirone, and S100B. Brain Res Dev Brain Res 131: 9-15, 2001.

ESNAFOGLU E, AYYILDIZ SN, CIRRIK S, ERTURK EY, ERDIL A, DAGLI A, NOYAN T: Evaluation of serum Neuron-specific enolase, S100B, myelin basic protein and glial fibrilliary acidic protein as brain specific proteins in children with autism spectrum disorder. Int J Dev Neurosci 61: 86-91, 2017.

FRAZER A, HENSLER JG: Serotonin involvement in physiological function and behavior. In: Basic Neurochemistry: Molecular, Cellular and Medical Aspects. SIEGEL GJ, AGRANOFF BW, ALBERS RW, FISHER SK, UHLER MD (eds), Philadelphia: Lippincott-Raven, 1999, Chapter 13, https://www.ncbi.nlm.nih.gov/books/NBK27940/.

GABRIELE S, SACCO R, PERSICO AM: Blood serotonin levels in autism spectrum disorder: a systematic review and meta-analysis. Eur Neuropsychopharmacol 24: 919-929, 2014.

GARBARINO VR, GILMAN TL, DAWS LC, GOULD GG: Extreme enhancement or depletion of serotonin transporter function and serotonin availability in autism spectrum disorder. Pharmacol Res 140: 85-99, 2019.

GAZZOLO D, PLUCHINOTTA F, LAPERGOLA G, FRANCHINI S: The Ca(2+)-Binding S100B protein: an important diagnostic and prognostic neurobiomarker in pediatric laboratory medicine. Methods Mol Biol 1929: 701-728, 2019.

GILBERT J, MAN HY: Fundamental elements in autism: from neurogenesis and neurite growth to synaptic plasticity. Front Cell Neurosci 11: 359, 2017.

GOSTNER JM, GEISLER S, STONIG M, MAIR L, SPERNER-UNTERWEGER B, FUCHS D: Tryptophan metabolism and related pathways in psychoneuroimmunology: the impact of nutrition and lifestyle. Neuropsychobiology: 1-11, 2019.

GULOKSUZ SA, ABALI O, AKTAS CETIN E, BILGIC GAZIOGLU S, DENIZ G, YILDIRIM A, KAWIKOVA I, GULOKSUZ S, LECKMAN JF: Elevated plasma concentrations of S100 calcium-binding protein B and tumor necrosis factor alpha in children with autism spectrum disorders. Braz J Psychiatry 39: 195-200, 2017.

HAO MM, CAPOCCIA E, CIRILLO C, BOESMANS W, VANDEN BERGHE P: Arundic acid prevents developmental upregulation of S100B expression and inhibits enteric glial development. Front Cell Neurosci 11: 42, 2017.

HARING JH, HAGAN A, OLSON J, RODGERS B: Hippocampal serotonin levels influence the expression of S100 beta detected by immunocytochemistry. Brain Res 631: 119-123, 1993.

HOLLANDER E, PHILLIPS A, CHAPLIN W, ZAGURSKY K, NOVOTNY S, WASSERMAN S, IYENGAR R: A placebo controlled crossover trial of liquid fluoxetine on repetitive behaviors in childhood and adolescent autism. Neuropsychopharmacology 30: 582-589, 2005.

HUANG M, DONG XQ, HU YY, YU WH, ZHANG ZY: High S100B levels in cerebrospinal fluid and peripheral blood of patients with acute basal ganglial hemorrhage are associated with poor outcome. World J Emerg Med 1: 22-31, 2010.

ISRAELYAN N, MARGOLIS KG: Serotonin as a link between the gut-brain-microbiome axis in autism spectrum disorders. Pharmacol Res 132: 1-6, 2018.

JAMESON KG, HSIAO EY: Linking the gut microbiota to a brain neurotransmitter. Trends Neurosci 41: 413-414, 2018.

KISER D, STEEMERS B, BRANCHI I, HOMBERG JR: The reciprocal interaction between serotonin and social behaviour. Neurosci Biobehav Rev 36: 786-798, 2012.

KOYAMA R, IKEGAYA Y: Microglia in the pathogenesis of autism spectrum disorders. Neurosci Res 100: 1-5, 2015.

LANDA RJ: Efficacy of early interventions for infants and young children with, and at risk for, autism spectrum disorders. Int Rev Psychiatry 30: 25-39, 2018. 
LANGNESS S, KOJIMA M, COIMBRA R, ELICEIRI BP, COSTANTINI TW: Enteric glia cells are critical to limiting the intestinal inflammatory response after injury. Am J Physiol Gastrointest Liver Physiol 312: G274-G282, 2017.

LIU J, WANG H, ZHANG L, XU Y, DENG W, ZHU H, QIN C: S100B transgenic mice develop features of Parkinson's disease. Arch Med Res 42: 1-7, 2011.

LORD C, RUTTER M, DILAVORE PC, RISI S, GOTHAM K, BISHOP S: Autism diagnostic observation schedule. Western Psychological Services, Torrance, CA, 2012, Modules 1-4.

LORD C, RUTTER M, LE COUTEUR A: Autism diagnostic interview-revised: a revised version of a diagnostic interview for caregivers of individuals with possible pervasive developmental disorders. J Autism Dev Disord 24: 659-685, 1994.

MARCHI N, RASMUSSEN P, KAPURAL M, FAZIO V, KIGHT K, MAYBERG MR, KANNER A, AYUMAR B, ALBENSI B, CAVAGLIA M, JANIGRO D: Peripheral markers of brain damage and blood-brain barrier dysfunction. Restor Neurol Neurosci 21: 109-121, 2003.

MARLER S, FERGUSON BJ, LEE EB, PETERS B, WILLIAMS KC, MCDONNELL E, MACKLIN EA, LEVITT P, GILLESPIE CH, ANDERSON GM, MARGOLIS KG, BEVERSDORF DQ, VEENSTRA-VANDERWEELE $\mathrm{J}$ : Brief report: whole blood serotonin levels and gastrointestinal symptoms in autism spectrum disorder. J Autism Dev Disord 46: 1124-1130, 2016.

MICHETTI F, D'AMBROSI N, TOESCA A, PUGLISI MA, SERRANO A, MARCHESE E, CORVINO V, GELOSO MC: The S100B story: from biomarker to active factor in neural injury. J Neurochem 148: 168-187, 2019.

MOHAMMAD-ZADEH LF, MOSES L, GWALTNEY-BRANT SM: Serotonin: a review. J Vet Pharmacol Ther 31: 187-199, 2008.

MULDER EJ, ANDERSON GM, KEMPERMAN RF, OOSTERLOO-DUINKERKEN A, MINDERAA RB, KEMA IP: Urinary excretion of 5-hydroxyindoleacetic acid, serotonin and 6-sulphatoxymelatonin in normoserotonemic and hyperserotonemic autistic individuals. Neuropsychobiology 61: 27-32, 2010.

MULLER CL, ANACKER AMJ, VEENSTRA-VANDERWEELE J: The serotonin system in autism spectrum disorder: From biomarker to animal models. Neuroscience 321: 24-41, 2016.

OCHOA-CORTES F, TURCO F, LINAN-RICO A, SOGHOMONYAN S, WHITAKER E, WEHNER S, CUOMO R, CHRISTOFI FL: Enteric Glial Cells: A new frontier in neurogastroenterology and clinical target for inflammatory bowel diseases. Inflamm Bowel Dis 22: 433-449, 2016.

ONAOLAPO AY, ONAOLAPO OJ: Global data on autism spectrum disorders prevalence: a review of facts, fallacies and limitations. Univ J Clin Med 5: 14-23, 2017.

PORTELA LV, TORT AB, SCHAF DV, RIBEIRO L, NORA DB, WALZ R, ROTTA LN, SILVA CT, BUSNELLO JV, KAPCZINSKI F, GONÇALVES CA, SOUZA DO: The serum S100B concentration is age dependent. Clin Chem 48: 950-952, 2002.

SCHULTE S, PODLOG LW, HAMSON-UTLEY JJ, STRATHMANN FG, STRUDER HK: A systematic review of the biomarker S100B: implications for sport-related concussion management. J Athl Train 49: 830-850, 2014.

SHAKER NM, TAHA G, KHOLEIF H, SAYED NM, MM E-S, ABULMAGD ML: Serum levels of S100b, interleukin-6 and anti-transglutaminase Ii IgA as immune markers in a sample of Egyptian children with autistic spectrum disorders. Autism Open Access 6: 1000191, 2016.

SHAPIRO LA, BIALOWAS-MCGOEY LA, WHITAKER-AZMITIA PM: Effects of S100B on serotonergic plasticity and neuroinflammation in the hippocampus in Down syndrome and Alzheimer's disease: studies in an S100B overexpressing mouse model. Cardiovasc Psychiatry Neurol 2010: pii: 153657, 2010.

SORCI G, RIUZZI F, ARCURI C, TUBARO C, BIANCHI R, GIAMBANCO I, DONATO R: S100B protein in tissue development, repair and regeneration. World J Biol Chem 4: 1-12, 2013.

STROTH N, SVENNINGSSON P: S100B interacts with the serotonin 5-HT7 receptor to regulate a depressive-like behavior. Eur Neuropsychopharmacol 25: 2372-2380, 2015.

TANG KW, TOH QC, TEO BW: Normalisation of urinary biomarkers to creatinine for clinical practice and research-when and why. Singapore Med J 56: 7-10, 2015.

TAY TL, BECHADE C, D'ANDREA I, ST-PIERRE MK, HENRY MS, ROUMIER A, TREMBLAY ME: Microglia gone rogue: impacts on psychiatric disorders across the lifespan. Front Mol Neurosci 10: 421, 2017. 
TOMOVA A, HUSAROVA V, LAKATOSOVA S, BAKOS J, VLKOVA B, BABINSKA K, OSTATNIKOVA D: Gastrointestinal microbiota in children with autism in Slovakia. Physiol Behav 138: 179-187, 2015.

VILLARREAL A, SEOANE R, GONZALEZ TORRES A, ROSCISZEWSKI G, ANGELO MF, ROSSI A, BARKER PA, RAMOS AJ: S100B protein activates a RAGE-dependent autocrine loop in astrocytes: implications for its role in the propagation of reactive gliosis. $J$ Neurochem 131: 190-205, 2014.

WANG-SATTLER R, YU Y, MITTELSTRASS K, LATTKA E, ALTMAIER E, GIEGER C, LADWIG KH, DAHMEN N, WEINBERGER KM, HAO P, LIU L, LI Y, WICHMANN HE, ADAMSKI J, SUHRE K, ILLIG T: Metabolic profiling reveals distinct variations linked to nicotine consumption in humans--first results from the KORA study. PLoS One 3: e3863, 2008.

XU G, LI Y, MA C, WANG C, SUN Z, SHEN Y, LIU L, LI S, ZHANG X, CONG B: Restraint stress induced hyperpermeability and damage of the blood-brain barrier in the amygdala of adult rats. Front Mol Neurosci 12: 32, 2019.

ZEIDAN-CHULIA F, SALMINA AB, MALINOVSKAYA NA, NODA M, VERKHRATSKY A, MOREIRA JC: The glial perspective of autism spectrum disorders. Neurosci Biobehav Rev 38: 160-172, 2014. 